\title{
FAKTOR YANG BERHUBUNGAN DENGAN PENGETAHUAN TB PARU DAN DUKUNGAN SOSIAL PASIEN RS KHUSUS PARU RESPIRA
}

\author{
Siti Fadlilah* $\diamond$, Eddy Aryanto** \\ *Program Pendidikan Profesi Ners Universitas Respati Yogyakarta \\ **RSUP Persahabatan Jakarta \\ $\diamond$ Corresponding Outhor: sitifadlilah@respati.ac.id
}

\begin{abstract}
Penelitian mengetahui hubungan usia, jenis kelamin, dan pengetahuan dengan pengetahuan tentang TB Paru dan dukungan sosial keluarga. Penelitian merupakan deskriptif kuantitatif dengan rancangan cross sectional. Sampel sebanyak 79 responden dengan total sampling. Instrumen yang digunakan adalah kuesioner. Analisa menggunakan Uji Spearman Rank. Hasil usia, jenis kelamin, dan tingkat pendidikan dengan tingkat pengetahuan tentang TB Paru didapatkan $p$-value 0,021;0,004; dan 0,01. Analisis usia, jenis kelamin, tingkat pendidikan, dan tingkat pengetahuan dengan dukungan sosial keluarga didapatkan p-value 0,035; 0,037; 0,006; dan 0,000. Ada hubungan antara usia, jenis kelamin, dan pendidikan dengan dengan pengetahuan tentang TB. Ada hubungan antara usia, jenis kelamin, pendidikan, dan pengetahuan dengan dukungan sosial keluarga.
\end{abstract}

Kata kunci: Dukungan Keluarga, Pengetahuan, Tuberkulosis Paru

\section{LATAR BELAKANG}

Tuberkulosis masih menjadi permasalahan utama kesehatan masyarakat selain mempengaruhi produktivitas kerja masyarakat, juga merupakan penyebab utama kematian. Word Health Organization (WHO) memperkirakan bahwa sepertiga penduduk dunia (2 miliar orang) telah terinfeksi oleh Mycobakterium tuberculosis, dengan angka tertinggi di Afrika, Asia, dan Amerika Latin. Jumlah penderita Tuberkulosis paru (TB Paru) di atas HIV/AIDS. Pada tahun 2016 diperkirakan kasus baru sebanyak 10,4 juta atau 142 kasus/100.000, dengan 480.000 kasus multidrug-resistant. Sebesar $60 \%$ kasus baru terjadi di 6 negara yaitu India, Indonesia, China, Nigeria, Pakistan dan Afrika Selatan. Kematian akibat tuberkulosis diperkirakan sebanyak 1,3 juta kematian ditambah 374.000 kematian akibat tuberkulosis pada orang dengan HIV positif. TB Paru menjadi 9 penyebab kematian tertinggi di dunia pada tahun 2016 (WHO, 2017).

WHO (2009), mencatat peringkat Indonesia menurun ke posisi lima dengan jumlah penderita TB paru sebesar 429 ribu. Lima negara dengan jumlah terbesar kasus insiden pada tahun 2009 adalah, China, Afrika Selatan, Nigeria, dan Indonesia. Indonesia merupakan negara dengan jumlah kasus baru terbanyak kedua di dunia setelah India (WHO, 2009). Di Indonesia setiap tahun ditemukan 539.0000 kasus baru TB BTA positif dengan kematian 101.000. Menurut catatan Departemen kesehatan sepertiga penderita tersebut ditemukan di RS dan sepertiga lagi dipuskesmas, sisanya tidak terdeteksi dengan baik (Department Of Health, 2012).

Pada tahun 2015 jumlah semua kasus tuberkulosis di Indonesia sebesar 330.729 dan meningkat menjadi 351.893 pada tahun 2016. Jumlah kasus tertinggi yang dilaporkan terdapat di provinsi dengan jumlah penduduk yang besar yaitu Jawa Barat sebanyak 23.774 orang, Jawa Timur sebanyak 21.606 orang dan Jawa Tengah sebanyak 14.139 orang. Kasus tuberkulosis di tiga provinsi tersebut sebesar $44 \%$ dari jumlah seluruh kasus baru di Indonesia (Kemenkes.RI, 2016).

Angka prevalensi suspek TB Paru DIY mencapai 64 orang/100.000 penduduk. Data terakhir Dinas Kesehatan DIY menyebutkan, sebanyak 16.662 warga DIY suspek TB Paru.Sebanyak 1.300 di antaranya positif mengidap TB Paru. Kota Yogyakarta 
diketahui menjadi wilayah dengan pengidap TB Paru terbanyak, mencapai 679 Jiwa, Sleman sebanyak 408 Jiwa, Bantul 338 Jiwa, Gunungkidul 309 Jiwa, dan terakhir Kulonprogo 158 Jiwa (DIY, 2013).

Pemerintah Indonesia dalam pengobatan dan penanggulangan Penyakit tuberkulosis sejak tahun 1990 bersama internasional Union Agains Tuberkulosis and Lung Disease (IUATLD) telah mengembangkan strategi penanggulangan TB yang dikenal sebagai strategi Directly Ovserved Treatment Shortcuose (DOTS) dan telah terbukti secara ekonomis paling efektif (Depkes RI, 2007). Pada Terapi DOTS, obat diberikan dalam jangka waktu yang lama. Penderita harus minum obat selama enam bulan berturut-turut tanpa putus. Dukungan keluarga sangat penting untuk mengontrol dan mendampingi penderita TB Paru (Setyaningsih, 2008).

Keluarga berfungsi sebagai sebuah kolektor dan diseminator (penyebar) informasi tentang dunia. Menjelaskan tentang pemberian saran, sugesti, informasi yang dapat digunakan mengungkapkan suatu masalah. Manfaat dari keluarga ini dalam terapi pengobatan TB paru adalah dapat menekan munculnya suatu stressor karena informasi yang diberikan dapat menyumbangkan aksi sugesti yang dapat membantu mengurangi kecemasaan yang disebabkan oleh penyakit TB Paru. Keluarga dapat menghilangkan godaan pada ketidaktaatan, dan mereka seringkali dapat menjadi kelompok pendukung untuk mencapai kesembuhan (Setyaningsih \& D., 2008).

Berdasarkan studi pendahuluan yang dilakukan peneliti di Rumah Sakit Khusus Paru Respira Yogyakarta, pada tanggal didapatkan data jumlah pasien TB Paru pada tahun 2016 sebanyak 112 orang, laki-laki 74 dan orang perempuan 38 orang, usia laki-laki berkisar 1 sampai dengan 71 tahun dan perempuan berusia berkisar 2 tahun sampai 80 tahun. Berdasarkan wawancara dengan 5 orang keluarga pasien TB Paru, didapatkan data 3 orang yang mampu menjawab dengan baik saat ditanyakan tentang TB Paru sedangkan 2 orang kurang memahami tentang TB Paru. Saat ditanyakan tentang dukungan sosial keluarga terhadap pengobatan pasien sebagian besar mengatakan kadang-kadang mengingatkan pasien untuk minum obat. Seluruh keluarga mengatakan tidak mengawasi sampai dengan obat diminum pasien. Berdasarkan hasil studi pendahuluan yang telah diuraikan peneliti ingin mengetahui hubungan tingkat pengetahuan tentang TB Paru dengan dukungan sosial keluarga kepada pasien dalam menjalani terapi di Rumah Sakit Khusus Paru Respira Yogyakarta.

\section{METODE}

Penelitian ini merupakan penelitian deskriptif kuantitatif dengan rancangan cross sectional. Populasi dalam penelitian ini adalah keseluruhan keluarga pasien yang menderita TB Paru yang memeriksakan diri di Rumah Sakit Khusus Paru Respira Yogyakarta, dengan jumlah sampel 79 orang. Kriteria inklusi yaitu satu pasien diwakili oleh satu anggota keluarga, bersedia menjadi responden, keluarga pasien menjalani pengobatan TB Paru, bisa membaca dan menulis, usia 20-59 tahun. Jumlah sampel 79 responden diambil dengan teknik total sampling. Variabel bebas yaitu usia, jenis kelamin, tingkat pendidikan, dan tingkat pengetahuan keluarga. Sedangkan variabel terikat yaitu tingkat pengetahuan dan dukungan sosial keluarga. Instrumen penelitian berupa kuesioner. Analisis bivariat menggunakan Uji Spearman Rank (Rho).

\section{HASIL}

\section{Analisis Univariat}

Kararakteristik responden pada penelitian ini sebagian besar berusia 36-55 tahun sebanyak 50 responden $(63,3 \%)$, berjenis kelamin laki-laki sebanyak 47 responden $(59,5 \%)$, tingkat pendidikannya menengah sebanyak 38 responden $(48,1 \%)$, tingkat pengetahuanya kategori cukup sebanyak 40 responden $(50,6 \%)$ dan dukungan sosial keluarga dalam kategori baik sebanyak 37 responden (46,9\%). 


\section{Analisis Bivariat}

Tabel 1: Distribusi Faktor-Faktor yang Berhubungan dengan Tingkat Pengetahuan tentang TB Paru

\begin{tabular}{|c|c|c|c|c|c|c|c|c|c|}
\hline \multirow{3}{*}{$\begin{array}{c}\text { Variabel } \\
\text { Independen }\end{array}$} & \multicolumn{8}{|c|}{ Tigkat Pengetahuan } & \multirow{3}{*}{ p-value } \\
\hline & \multicolumn{2}{|c|}{ Baik } & \multicolumn{2}{|c|}{ Cukup } & \multicolumn{2}{|c|}{ Kurang } & \multicolumn{2}{|c|}{ Total } & \\
\hline & $\mathrm{f}$ & $\%$ & $f$ & $\%$ & $\mathrm{f}$ & $\%$ & $\mathrm{~F}$ & $\%$ & \\
\hline \multicolumn{10}{|l|}{ Usia } \\
\hline $17-35$ & 2 & 22,2 & 4 & 44,4 & 3 & 33,3 & 9 & 100,0 & \\
\hline $36-55$ & 18 & 36,0 & 22 & 44,0 & 10 & 20,0 & 50 & 100,0 & 0,021 \\
\hline $56-65$ & 3 & 15,0 & 14 & 70,0 & 3 & 15,0 & 20 & 100,0 & \\
\hline Total & 23 & 29,1 & 40 & 50,6 & 16 & 20,3 & 79 & 100,0 & \\
\hline \multicolumn{10}{|l|}{ Jenis Kelamin } \\
\hline Lakk-laki & 3 & 6,4 & 32 & 68,1 & 12 & 25,5 & 47 & 1000 & \\
\hline Perempuan & 20 & 62,5 & 8 & 25,0 & 4 & 12,5 & 32 & 100,0 & 0,0 \\
\hline Total & 23 & 29,1 & 40 & 50,6 & 16 & 20,3 & 79 & 100,0 & \\
\hline \multicolumn{10}{|l|}{ Pendidikan } \\
\hline Dasar & 5 & 16,7 & 11 & 36,7 & 14 & 46,7 & 30 & 100,0 & \\
\hline Menegah & 10 & 26,3 & 26 & 68,4 & 2 & 5,3 & 38 & 100,0 & 0,001 \\
\hline Tinggi & 8 & 72,1 & 3 & 27,3 & 0 & 0,0 & 11 & 100,0 & \\
\hline Total & 23 & 29,1 & 40 & 50,6 & 16 & 20,3 & 79 & 100,0 & \\
\hline
\end{tabular}

Berdasarkan tabel di atas diketahui analisis hubungan usia, jenis kelamin, dan tingkat pendidikan dengan tingkat pengetahuan tentang TB Paru didapatkan pvalue 0,$021 ; 0,004$; dan 0,01 . Hal tersebut menunjukkan ada hubungan antara usia, jenis kelamin, dan tingkat pendidikan dengan dengan tingkat pengetahuan tentang TB Paru di Rumah Sakit Khusus Paru Respira Yogyakarta.

Tabel 2: Distribusi Faktor-Faktor yang Berhubungan dengan Dukungan Sosial pada Keluarga Pasien

\begin{tabular}{|c|c|c|c|c|c|c|c|c|c|}
\hline \multirow{3}{*}{$\begin{array}{c}\text { Variabel } \\
\text { Independen }\end{array}$} & \multicolumn{8}{|c|}{ Dukungan Keluarga } & \multirow{3}{*}{$\mathrm{p}$-value } \\
\hline & \multicolumn{2}{|c|}{ Baik } & \multicolumn{2}{|c|}{ Cukup } & \multicolumn{2}{|c|}{ Kurang } & \multicolumn{2}{|c|}{ Total } & \\
\hline & $\mathrm{f}$ & $\%$ & f & $\%$ & $\mathrm{f}$ & $\%$ & $\mathrm{~F}$ & $\%$ & \\
\hline \multicolumn{10}{|l|}{ Usia } \\
\hline $17-35$ & 2 & 22,2 & 2 & 22,2 & 5 & 55,6 & 9 & 100,0 & \\
\hline $36-55$ & 18 & 36,0 & 20 & 40,0 & 12 & 24,0 & 50 & 100,0 & 0,035 \\
\hline $56-65$ & 17 & 85,0 & 3 & 15,0 & 0 & 0,0 & 20 & 100,0 & \\
\hline Total & 37 & 46,8 & 25 & 31,6 & 17 & 21,5 & 79 & 100,0 & \\
\hline \multicolumn{10}{|l|}{ Jenis Kelamin } \\
\hline Lakk-laki & 22 & 46,8 & 9 & 19,1 & 16 & 34,0 & 47 & 100,0 & 0.037 \\
\hline Perempuan & 15 & 46,9 & 16 & 50,0 & 1 & 3,1 & 32 & 100,0 & 0,037 \\
\hline Total & 37 & 46,8 & 25 & 31,6 & 17 & 21,5 & 79 & 100,0 & \\
\hline \multicolumn{10}{|l|}{ Pendidikan } \\
\hline Dasar & 9 & 30,0 & 6 & 20,0 & 15 & 50,0 & 30 & 100,0 & \\
\hline Menegah & 20 & 52,6 & 17 & 44,7 & 1 & 2,6 & 38 & 100,0 & 0,006 \\
\hline Tinggi & 8 & 72,7 & 2 & 18,2 & 1 & 9,1 & 11 & 100,0 & \\
\hline Total & 37 & 46,8 & 25 & 31,6 & 17 & 21,5 & 79 & 100,0 & \\
\hline \multicolumn{10}{|l|}{ Pengetahuan } \\
\hline Baik & 15 & 65,2 & 5 & 21,7 & 3 & 13,0 & 23 & 100,0 & \\
\hline Culup & 18 & 45,0 & 18 & 45,0 & 4 & 10,0 & 40 & 100,0 & 0,000 \\
\hline Kurang & 4 & 25,0 & 2 & 12,5 & 10 & 62,5 & 16 & 100,0 & \\
\hline Total & 37 & 46,8 & 25 & 31,6 & 17 & 21,5 & 79 & 100,0 & \\
\hline
\end{tabular}

Berdasarkan tabel di atas diketahui analisis hubungan usia, jenis kelamin, tingkat pendidikan, dan tingkat pengetahuan dengan dukungan sosial keluarga didapatkan p-value 0,035; 0,037; 0,006; dan 0,000. Hal tersebut menunjukkan ada hubungan antara usia, jenis kelamin, tingkat pendidikan, dan tingkat pengetahuan dengan dukungan sosial keluarga di di Rumah Sakit Khusus Paru Respira Yogyakarta.

\section{PEMBAHASAN}

Hasil penelitian menunjukkan bahwa sebagian besar tingkat pengetahuan tentang TB Paru responden di rumah sakit khusus paru respira Yogyakarta berada pada kategori cukup. Notoatmodjo (2010), menjelaskan pengetahuan adalah hasil pengindraan manusia, atau hasil tahu seseorang terhadap objek melalui indera yang dimilikinya (mata, hidung, telinga, dan sebagainya). Dengan sendirinya, pada waktu penginderaan sampai menghasilkan pengetahuan tersebut sangat dipengaruhi oleh intensitas perhatian dan persepsi terhadap objek. Sebagian besar pengetahuan seseorang diperoleh melalui indera pendengaran (telinga), dan indera penglihatan (mata) (Notoadmodjo, 2010).

Pengetahuan responden yang baik dipengaruhi oleh umur. Semakin cukup umur, tingkat kematangan dan kekuatan seseorang akan lebih matang dalam berfikir dan bekerja (Wawan \& Dewi, 2010). Hasil penelitian menunjukkan pengetahuan baik mayoritas pada usia dewasa tengah (36-55 tahun). Hasil analisis bivariat didapatkan pvalue $0,021 \quad(p<0,05)$, berarti ada hubungan antara usia dengan tingkat pengetahuan. Astuti (2011), menyatakan ada hubungan antara umur dengan tingkat pengetahuan seseorang $(\mathrm{p}=0,001)$. Sebagian responden berusia matang, dimana pada usia tersebut akan mempunyai daya tangkap dan daya pikir baik sehingga pengetahuan yang dimilikinya juga semakin membaik (Astuti, 2012). Menurut Verner dan Davison dalam Maulana (2007) menyatakan bahwa ada 6 faktor fisik yang dapat menghambat proses belajar pada orang dewasa diantaranya gangguan penglihatan dan pendengaran sehingga membuat penurunan pada suatu waktu dalam kekuatan berfikir dan bekerja. 
Terbukti pada penelitian ini, pada kelompok usia lansia tingkat pengetahuan semakin kurang dibandingkan dengan rentang usia dewasa awal dan dewasa tengah.

Tabel 2 diketahui tingkat pengetahuan perempuan lebih baik dibandingkan laki-laki. Hasill uji bivariat didapatkan $p$-value 0,001 $(p<0,05)$, berarti jenis kelamin mempunyai hubungan dengan tingkat perempuan. Perempuan lebih banyak suka membaca atau berdiskusi dengan orang lain sehingga pengetahuan tentang TB Paru lebih baik. Penelitian Berek dkk (2018), didapatkan hasil remaja perempuan mempunyai pengetahuan tentang HIV/AIDS dibandingkan laki-laki dengan p-value 0,015. Perempuan mempunyai sifat lebih rajin, tekun, ulet dan teliti ketika diberi tugas atau mengerjakan sesuatu. Hasil penelitian tidak mendukung penelitian Suwaryo dan Yuwono (2017), bahwa jenis kelamin tidak memiliki hubungan dengan tingkat pengetahuan warga masyarakat tentang mitigasi bencana alam tanah longsor dengan nilai $\mathrm{p}=0.787$ (Suwaryo et al., n.d.) (Berek, Be, Rua, \& Anugrahini, 2019).

Faktor lain yang dapat mempengaruhi pengetahuan adalah pendidikan. Semakin tinggi tingkat pendidikan semakin mudah mendapat informasi (Nugroho, Laksmi \& Priyonoadi, 2016). Dari hasil penelitian pada tabel 1 diketahui pada responden dengan tingkat pendidikan lebih tinggi mempunyai tingkat pengetahuan semakin baik. Hasil analisis pendidikan dengan tingkat pengetahuan didapatkan p-value 0,021 $(\mathrm{p}<0,05)$, berarti ada hubungan antara tingkat pendidikan dengan tingkat pengetahuan. Penelitian Sukmawati, Sari, dan Criswinda (2018), didapatkan semakin tinggi tingkat pendidikan semakin tinggi pengetahuan tentang penyakitnya (Sukmawati, \& Chriswinda, 2019). Sejalan dengan penelitian Fadlilah dan Rahil (2019), diketahui responden dengan pendidikan tinggi mempunyai pengetahuan tentang futsal lebih baik dibandingkan dengan pendidikan menengah (Fadlilah \& Rahil, 2019).

Hasil penelitian dapat disimpulkan bahwa sebagian besar dukungan sosial keluarga kepada pasien dalam menjalani terapi di Rumah Sakit Khusus Paru Respira
Yogyakarta ketegori baik. Dukungan sosial keluarga mengacu kepada dukungan sosial yang dipandang oleh keluarga sebagai sesuatu yang dapat diakses atau diadakan untuk keluarga (dukungan sosial bisa atau tidak digunakan, tetapi anggota keluarga memandang bahwa orang yang bersifat mendukung selalu siap memberikan pertolongan dan bantuan jika diperlukan). Dukungan sosial keluarga dapat berupa dukungan sosial kelurga internal, seperti dukungan dari suami atau istri serta dukungan dari saudara kandung atau dukungan sosial keluarga eksternal (Friedman, 2003). Dukungan sosial keluarga dalam penelitian ini dinilai dengan menggunakan kuesioner yang terdiri dari beberapa aspek antara lain dukungan informasional, dukungan penilaian, dukungan instrumental, dan dukungan emosional.

Tabel 2 diketahui dukungan sosial kepada pasien paling baik diberikan oleh keluarga dengan rentang usia 36-55 tahun. Usia tersebut termasuk dalam dewasa madya (middle adulthood). Masa ini Ini adalah masa untuk memperluas keterlibatan dan tanggung jawab pribadi dan sosial seperti membantu generasi berikutnya menjadi individu yang berkompeten, dewasa dan mencapai serta mempertahankan kepuasan dalam berkarir. Hail uji bivariat antara usia dengan dukungan sosial keluarga didapatkan p-value 0,035, berarti ada hubungan antara usia dengan dukungan sosial yang diberikan oleh keluarga. Semakin muda usia seseorang akan fokus pada diri sendiri untuk pembentukan kemandirian pribadi dan ekonomi, dan masa perkembangan karir.

Tabel 2 menunjukkan keluarga perempuan mempunyai dukungan keluarga lebih baik dibandingkan laki-laki. Jumlah keluarga yang memberikan dukungan sosial kurang lebih banyak laki-laki dibandingkan perempuan. Hasil bivariat antara jenis kelamin dengan dukungan sosial keluarga didapatkan p-value 0,037, berarti ada hubungan antara jenis kelamin dengan pemberian dukungan sosial. Menurut Johnson, dalam Bastable (2002), perempuan cenderung menjadi pendengar yang baik yang langsung menangkap fokus diskusi 
permasalahan dan tidak berfokus pada diri sendiri (Bastable, 2002).

Notoatmojo (2012), mengatakan bahwa pendidikan berhubungan langsung dengan pengetahuan seseorang, sehingga diasumsikan bahwa tingkat pendidikan yang lebih tinggi diharapkan dapat meningkatkan pengetahuan seseorang. Semakin tinggi pengetahuan diharapkan seseorang akan menerapkan ilmunya terutama saat anggota keluarga ada yang membutuhkan (Notoadmodjo, 2012).

Tabel 2 menjabarkan semakin tinggi tingkat pendidikan dan tingkat pengetahuan, semakin baik dukungan sosial yang diberikan kepada anggota keluarga yang sakit. Hasil uji bivariat pendidikan dan tingkat pengetahuan dengan dukungan sosial keluarga didapatkan p-value 0,006 dan 0,000. Artinya, ada hubungan bermakna antara pendidikan dan pengetahuan dengan dukungan sosial keluarga. Hasil penelitian ini mendukung penelitian Dhewi, Armiyati, dan Supriyono (2012), bahwa ada hubungan antara pengetahuan, sikap, dan dukungan keluarga dengan motivasi penderita TB paru untuk minum obat pada pasien TB di BKPM Pati, dengan nilai $p$-value sebesar $0,000(\alpha=0,05)$ (Dhewi, Armiyati, Supriyono, 2011).

\section{KESIMPULAN}

Hasil penelitian diketahui ada hubungan antara usia, jenis kelamin dan tingkat pendidikan dengan tingkat pengetahuan keluarga tentang TB Paru. Hasil juga menjelasakan adanya hubungan signifikan antara usia, jenis kelamin, tingkat pendidikan, dan tingkat pengetahuan dengandukungan sosial keluarga pasien TB Paru di Rumah Sakit Khusus Paru Respira Yogyakarta. Berdasarkan hasil penelitian diharapkan perawat dapat memberikan informasi lebih kepada keluarga tentang peran keluarga dalam penanganan pasien TB Paru. Pengobatan TB Paru yang jangka panjang membutuhkan dukungan dari berbagai pihak terutama keluarga.

\section{DAFTAR PUSTAKA}

Astuti, H. P. (2012). Hubungan Karakteristik Ibu Hamil dengan Tingkat Pengetahuan tentang Tanda Bahaya pada Kehamilan di Puskesmas Sidoharjo Kabupaten Sragen. Jurnal Kesehatan Kusuma Husada, 3(2).

Bastable, S. . (2002). Perawat Sebagai Pendidik: Prinsip-Prinsip Pengajaran dan Pembelajaran. Jakarta: EGC.

Berek, P. A. L., Be, M. F., Rua, Y. M., \& Anugrahini, C. (2019). Hubungan Jenis Kelamin Dan Umur Dengan Tingkat Pengetahuan Remaja Tentang Hiv/Aids Di Sman 3 Atambua Nusa Tenggara Timur 2018. Jurnal Sahabat Keperawatan, 1(01), 4-13.

Department Of Health. (2012). Centre for Disease Control (Pusat Pengendalian Penyakit) Tuberculosis (TB) Treatment (Perawatan Penyakit Tuberkulosis (TBC). Northem Territory Government, (March), 1-3.

Depkes RI. (2007). National guideline for the control of tuberculosis (Pedoman nasional penanggulangan tuberkulosis). 119. https://doi.org/616.995.24 Ind P

Dhewi, G., Armiyati, Y., Supriyono, M. (2011). Hubungan Antara Pengetahuan, Sikap, Dan Dukungan Keluarga Dengan Motivasi Penderita TB Paru Untuk Minum Obat Pada Pasien TB Di BKPM Pati. Jurnal Stikes Telogorjo.

DIY, D. K. (2013). Profil Kesehatan Kota Yogyakarta Tahun 2013.

Fadlilah, S., \& Rahil, N. H. (2019). FaktorFaktor Yang Berhubungan Dengan Perilaku Pencegahan Cidera Muskuloskeletal Pada Pemain Futsal. Jurnal Keperawatan BSI, 7(1).

Friedman, M. M. (2003). Keperawatan Keluarga teori dan praktik. Alih bahasa Monica Ester (3rd ed.). Jakarta: EGC.

Kemenkes.RI. (2016). Tuberkulosis Temukan Obati Sampai Sembuh. Gaceta Medica de Bilbao, Vol. 112, pp. 149-150. Jakarta: Pusat Data dan Informasi Kementrian RI. 
Maulana, H. (2007). Promosi Kesehatan. Jakarta: EGC.

Notoadmodjo, S. (2010). Promosi Kesehatan Teori dan Aplikasi. Jakarta: Rineka Cipta.

Notoadmodjo, S. (2012). Promosi Kesehatan dan Perilaku Kesehatan. Jakarta: Rineka Cipta.

Nugroho, B. S., Laksmi, R., Priyonoadi, B. (2016). Tingkat Pengetahuan Atlet Tentang Cedera Ankle Dan Terapi Latihan Di Persatuan Sepakbola Telaga Utama. Jurnal Medikora, 15(1), 23-38.

Setyaningsih, S. (2008). Peran suami terhadap kepatuhan berobat pada wanita penderita tubrtkulosis di Kabupaten Purworejo Jawa Tengah.

Sukmawati, E., Sari, N. N., \& Chriswinda B.M, A. (2019). Hubungan Tingkat Pengetahuan Pasien Diabetes Mellitus dengan Perawatan Luka Menggunakan Tekhik Modern Dressing (Studi RLS Sidoarjo). Jurnal Ilmiah Keperawatan Stikes Hang Tuah Surbaya, 14(1).
Suwaryo, P. \& Yuwono, P., Faktor-Faktor Yang Mempengaruhi Tingkat Pengetahuan Masyarakat dalam Mitigasi Bencana Alam Tanah Longsor. Jurnal Proseding Urecol. 304-315.

WHO. (2009). World Health Statistic 2009. Retrieved from https://www.who.int/ whosis/whostat/2009/en/

WHO. (2017). Global Tuberculosis Report 2017: Leave no one behind - Unite to end TB. In WHO - Technical Report Series;727. https://doi.org/10.1001/ jama.2014.11450 